\title{
A new species of the catfish genus Centromochlus (Siluriformes: Auchenipteridae: Centromochlinae) from the upper rio Paraná basin, Brazil
}

\author{
Luisa Maria Sarmento-Soares ${ }^{1}$ and José Luís Olivan Birindelli²
}

Centromochlus comprises twelve species, distributed in the main inland watersheds of South America, including the Orinoco, Essequibo, coastal rivers of Suriname, Amazon, upper Paraná and São Francisco basins. The new species is described from the upper rio Paraná based on material collected in 1965 during the construction of the UHE Ilha Solteira, São Paulo, Brazil. The new species is easily distinguished from all congeners due to absence of adipose fin, a condition otherwise restricted to Gelanoglanis nanonocticolus, among centromochlin catfishes. The new species comprises small catfishes (adults ranging from 35 to $39 \mathrm{~mm} \mathrm{SL}$ ), in which modified anal fin of males is devoid of denticulations or spines, and most posterior rays reduced in length. In addition, Tatia simplex Mees is transferred to Centromochlus and its generic reassignment discussed.

Centromochlus abriga doze espécies, com registros para os principais sistemas fluviais de águas interiores da América do Sul, como o Orinoco, Essequibo, rios costeiros do Suriname, Amazonas, alto Paraná e São Francisco. A nova espécie é descrita do alto rio Paraná, a partir de material coletado em 1965 durante a construção da UHE Ilha Solteira, São Paulo, Brasil. A espécie nova distingue-se facilmente de todas as suas congêneres pela ausência de nadadeira adiposa, uma condição até então restrita à Gelanoglanis nanonocticolus, dentre os bagres centromochlíneos. A nova espécie inclui pequenos bagres (adultos entre 35 e $39 \mathrm{~mm} \mathrm{CP}$ ), nos quais a nadadeira anal modificada em machos é desprovida de dentículos ou espinhos, e com os raios mais posteriores de tamanho reduzido. Adicionalmente, Tatia simplex Mees é transferida para Centromochlus e é fornecida uma discussão acerca de seu posicionamento genérico.

Keywords: Ostariophysi, South America, Systematics, Taxonomy, Tatia simplex.

\section{Introduction}

Centromochlusisamemberofthefamily Auchenipteridae and, together with Gelanoglanis, Glanidium and Tatia, compose the subfamily Centromochlinae (Ferraris, 2007). Centromochlus was proposed by Kner (1858) to encompass his new species C. megalops and C. aulopygius, the former designated by Bleeker (1862) as the type species. Mees (1974) restricted Centromochlus to two nominal species, C. existimatus Mees, 1974, and C. heckelii (De Philippi, 1853) with C. megalops as a junior synonym of the latter. A comprehensive phylogenetic analysis of Centromochlinae (Soares-Porto, 1998) supported C. existimatus and $C$. heckelii as sister species derived within a clade that included species previously assigned to Gelanoglanis and Tatia. Subsequent studies (Sarmento-Soares \& MartinsPinheiro, 2008; Sarmento-Soares \& Martins-Pinheiro, 2013) have revised Centromochlus to include C. altae Fowler, 1945, C. bockmanni (Sarmento-Soares \& Buckup, 2005), C. concolor (Mees, 1974), C. macracanthus Soares-Porto, 2000, C. meridionalis Sarmento-Soares, Cabeceira, Carvalho, Zuanon \& Akama, 2013, C. perugiae Steindachner, 1883, C. punctatus (Mees, 1974), C. reticulatus (Mees, 1974), C. romani (Mees, 1988) and C. schultzi Rössel, 1962, in addition to C. existimatus, and $C$. heckelii. Tatia, on the other hand, was described

\footnotetext{
${ }^{1}$ Instituto Nacional da Mata Atlântica, Av. José Ruschi, 4, Centro, 29650-000 Santa Teresa, ES, Brazil and Programa de Pós-Graduação em Biologia Animal, Universidade Federal do Espírito Santo. Av. Marechal Campos, 1468, Prédio da Biologia, Campus de Maruípe, 29043-900 Vitória, ES, Brazil. luisa@nossosriachos.net

${ }^{2}$ Departamento de Biologia Animal e Vegetal, Universidade Estadual de Londrina, Caixa Postal 6001, 86051-980 Londrina, Paraná, Brazil.josebirindelli@yahoo.com
} 
by Miranda Ribeiro (1911) to allocate Centromochlus aulopygius. Subsequently, Mees (1974) expanded Tatia to 14 species, and Soares-Porto (1998) redefined the genus to include only eight species. Tatia was revised by SarmentoSoares \& Martins-Pinheiro (2008), and now comprise 17 valid species with six of them described in the last five years (Sarmento-Soares \& Martins-Pinheiro, 2008; Pavanelli \& Bifi, 2009; Vari \& Ferraris, 2013; Vari \& Calegari, 2014). Glanidium was described by Lütken (1875) and includes the largest species of Centromochlinae, all geographically restricted to southern and southeastern Brazil, except for G. leopardum (Hoedeman, 1961) from the coastal rivers of the Guianas. Gelanoglanis, described by Böhlke (1980), is a genus encompassing three miniature species distributed in the Amazon and Orinoco basins (Soares-Porto et al., 1999; Rengifo et al., 2008).

The limits between the genera of Centromochlinae remain poorly defined. Although considered valid by most authors (Soares-Porto et al., 1999; Ferraris, 2003, 2007; Rengifo et al., 2008), Gelanoglanis nested deeply within Centromochlus in the phylogeny by Soares-Porto (1998). Glanidium bockmanni was recently transferred to Centromochlus (Sarmento-Soares \& Martins-Pinheiro, 2013). Tatia musaica Royero, 1992 was recently transferred to Centromochlus (Sarmento-Soares \& Martins-Pinheiro, 2008), but then returned to Tatia (Vari \& Ferraris, 2013). In addition, the validity of some species assigned to Centromochlus need additional investigation, including C. megalops, considered as a species inquirendae in Centromochlus (Ferraris, 2007), "Centromochlus" simplex Mees, 1974, ranked as incertae sedis in Centromochlinae (Sarmento-Soares \& Martins Pinheiro, 2008), and $C$. steindachneri Gill, 1870, tentatively considered a synonym of $C$. heckelii by Mees (1974) but possibly valid (LMSS, per. obs.).

Species of Centromochlus are distributed widely in South American, occurring in the Orinoco basin in Venezuela and Colombia, in the Amazon basin from Ecuador to Brazil, and in the coastal rivers of northern South America between the mouths of the Orinoco and Amazon rivers from the Guianas to Brazil (Soares-Porto, 1998; Ferraris, 2003, 2007; Akama \& Sarmento-Soares, 2007). Centromochlus sensu Soares-Porto (1998) was defined as monophyletic group based on the following synapomorphies: elongate maxilla, about 35 to $45 \%$ longer than palatine; anterior nuchal plate absent; elongate ventrolateral process of infraorbital 1 (lacrimal), forming the anterior border of the orbital rim, with the infraorbital canal extending through this process to its tip. However, Gelanoglanis can be distinguished from Centromochlus by having only a single pair of mental barbels; premaxillary tooth patches laterally oriented and widely separated anteriorly at midline; posterior naris large and immediately anterior to eye; oblique, sinuous mouth with free fleshy flange around angle of gape, and dorsal, anal, and paired fins with short base and few rays (Soares-Porto et al., 1999).
Large hydroelectric dams were built in São Paulo, the most populous state of Brazil, working since in the 1960s. Those large dams had a significant impact on the rivers and fish communities in the upper rio Paraná basin. The Usina Hidrelétrica de Ilha Solteira was one of the first dams built between 1965 and 1978 in a stretch of rio Paraná between Ilha Solteira (São Paulo) and Selvíria (Mato Grosso do Sul). It is the third largest dam in Brazil, and together with its neighbor, UHE Engenheiro Souza Dias (also known as UHE Jupiá), the both dams compose the sixth largest hydroelectric complex in the world (Shibatta \& Dias, 2006). During the construction of the UHE Ilha Solteira, expeditions to the area resulted in the capture of several species now considered rare (i.e, collected only during that opportunity or very few times in other places), including Apteronotus acidops Triques, 2011, Sternarchorhynchus britskii Campos-da-Paz, 2000, and Tembeassu marauna Triques, 1998. The first two species are listed as threatened on the Brazilian Red List (Brasil. MMA, 2014). During the same expeditions, the new species of Centromochlus was collected. The new species was incorrectly identified as Glanidium cesarpintoi, a poorly known species of Centromochlinae described by Ihering (1928) to the rio Mogi Guaçu, upper rio Paraná basin. The misidentification left the new species undescribed for more than 50 years. The aim of the present contribution is to describe the species as new, diagnosing it from all other Centromochlinae. In addition, comments on Centromochlus simplex are provided and its generic placement discussed.

\section{Material and Methods}

Osteological features were examined in cleared and stained (CS) specimens prepared according to the procedures of Taylor \& Van Dyke (1985). Prior to clearing and staining, specimens were dissected when possible to determine gut contents, sexual maturity of gonads, and to check myological characteristics. Osteological data for species poorly represented in collections were obtained from radiographs. Specimens examined via radiographs are noted as " $R$ " in the Material examined section. Nomenclature for osteological elements is based on Weitzman (1962), Fink \& Fink (1981), Arratia (2003), including suggestions by Britto $(2002,13)$ and Birindelli (2014); most terms follow the Zebrafish Information Network (ZFIN). Muscle names follow Sarmento-Soares \& Porto (2006). Drawings were rendered from camera lucida or digital photographs, preferably of CS specimens.

Straight-line measurements were made with a digital caliper, and recorded in tenths of a millimeter. Measurements and counts follow Sarmento-Soares \& Martins-Pinheiro (2008). Counts of fin rays and bony elements were obtained from alcohol-preserved and CS specimens. Vertebral counts include the five elements incorporated into the Weberian complex and one terminal 
element associated with the hypural complex (following Vari \& Ferraris, 2013). Counts of branchiostegal rays were performed only on CS specimens.

Institutional abbreviations are as follow: American Museum of Natural History, New York (AMNH); Natural History Museum (formely British Museum Natural History), London; Coleção de Peixes do Departamento de Zoologia e Botânica do Instituto de Biociências, Letras e Ciências Exatas, São José do Rio Preto (DZSJRP); Instituto Nacional de Pesquisas da Amazônia, Manaus (INPA); Museu de Biologia Professor Mello Leitão, Santa Teresa (MBML); Museu Nacional, Rio de Janeiro (MNRJ); Museu de Zoologia da Universidade Estadual de Londrina, Londrina (MZUEL); Museu de Zoologia da Universidade de São Paulo, São Paulo (MZUSP); Netherlands Centre for Biodiversity Naturalis (formerly Rijksmuseum van Natuurlijke Historie), Leiden (RMNH. PISC); Núcleo de Pesquisas em Limnologia, Ictiologia e Aquicultura,Universidade Estadual de Maringá, Maringá (NUP), and National Museum of Natural History, Smithsonian Institution, Washington DC (USNM).

\section{Results}

\section{Centromochlus britskii, new species}

urn:1sid:zoobank.org:act:06BA0384-4F94-4FF2-BDB0 4DFC9C584B44

Fig. 1

Glanidium cesarpintoi (non Ihering, 1928). -Sarmento-Soares \& Buckup, 2005: 846 (comparative material).

Holotype. MZUSP 115271, 39.2 mm SL, male, Brazil, São Paulo, rio Paraná where is now the UHE Ilha Solteira upper rio Paraná basin, approximately $20^{\circ} 18^{\prime} \mathrm{S} 51^{\circ} 10^{\prime} \mathrm{W}$, Sep 1965 , Excursion of Departamento de Zoologia da Secretaria de Agricultura do Estado de São Paulo, Heraldo A. Britski, Izáurio A. Dias \& Gustavo A. S. de Melo.

Paratypes. MZUSP 43251, $2 \mathrm{R}+1 \mathrm{CS}, 33.5-36.3 \mathrm{~mm}$ SL, MNRJ 41787, 2 R, 36.0-38.6 mm SL, collected with holotype, prior to the river dam.

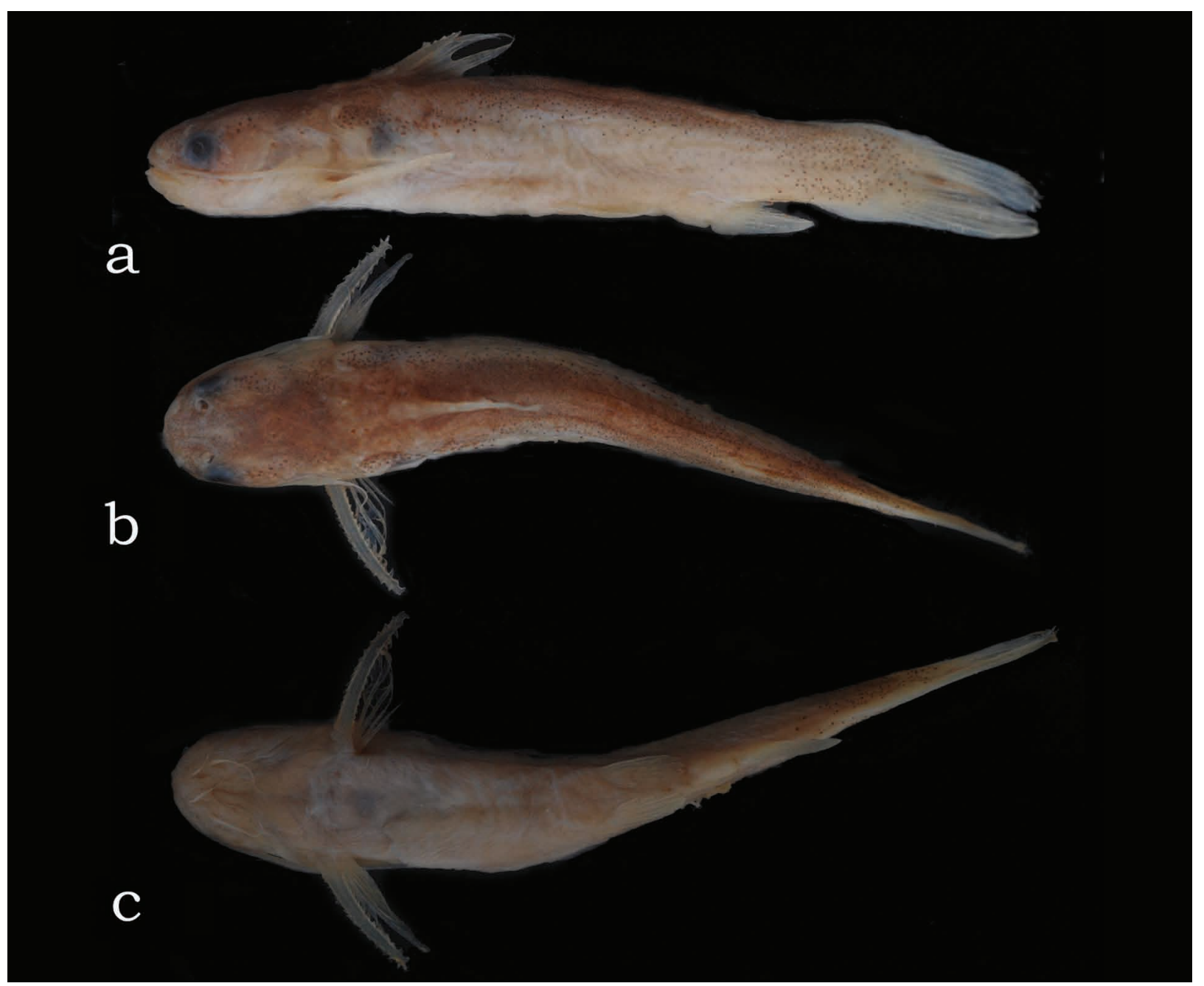

Fig. 1. Centromochlus britskii, new species, holotype, MZUSP 115271, male, $39.2 \mathrm{~mm}$ SL, UHE Ilha Solteira, upper rio Paraná basin, Ilha Solteira, São Paulo State, Brazil. Lateral (a), dorsal (b) and ventral (c) views. 
Diagnosis. Centromochlus britskii is distinguished from all Centromochlinae, except Gelanoglanis nanonocticolus Soares-Porto, Walsh, Nico \& Netto, 1999, by absence (vs. presence) of adipose fin. The new species differs from $G$. nanonocticolus by having two pairs (vs. one pair) of mental barbels, premaxillary tooth patches anteriorly united (vs. separated) and mouth gape straight and short (vs. large and sinuous).

The new species differs from congeners Centromochlus altae, C. existimatus, C. heckelii, C.perugiae, C. reticulatus, $C$. romani and $C$. meridionalis by having seven branched rays in the anal fin (vs. 5 or 6 ). Further distinguished from $C$. altae, C. existimatus, C. heckelii and C. perugiae by lacking anterior nuchal plate (vs. anterior nuchal plate present); from C. meridionalis and C. romani by having anterior margin of dorsal-fin spine with serrae (vs. dorsal-fin spine smooth); from $C$. existimatus and $C$. heckelii by having shorter pectoral-fin spine 20.7-22.7\% of SL ( $v s .29 .3-41.6 \%$ of SL).

Among species group that share the absence of anterior nuchal plate and seven branched anal-fin rays (i.e, $C$. punctatus, C. schultzi, C. macracanthus, C. bockmanni, C. simplex), the new species differs from both $C$. schultzi and $C$. macracanthus by having posterior border of dorsalfin spine smooth (vs. with denticules); from C. punctatus by the morphology of male modified anal fin, specifically, the last branched anal-fin ray progressively shorter than anterior most ( $v s$. last ray abruptly reduced, size half that of preceding one and visible only through dissection).

Description. Morphometric data in Table 1. Small size, examined adult specimens 33.6-39.2 mm SL. Body short, head slightly depressed. In dorsal view, profile of head longer than broad, slightly convex from snout tip to pectoral-fin insertion. In lateral view, dorsal profile of body from dorsalfin base to caudal fin slightly to distinctly convex. Ventral profile of head and abdomen almost straight. Ventral profile of body gently concave between anal-fin base and caudalfin origin. Trunk from dorsal-fin base to caudal peduncle gradually compressed. Head integument thick, bones of cranial roof not discernible; adipose eyelid weakly developed; eye dorsolateral on anterior portion of head; mouth terminal, upper lip extended posterolaterally, fleshy rictal fold well developed; snout margin rounded in dorsal view; anterior nostril tubular, located on anterior border of snout; posterior nostril somewhat larger, rounded, limited anteriorly by small skin flap; transverse distance between anterior nostrils almost equal to distance between posterior ones. Maxillary barbel elongate, extending well beyond membranous border of opercle, reaching approximately vertical through dorsalfin origin; adpressed maxillary barbel fits in groove on the lateral portion of head, immediately above rictal fold and below eye; mental barbels short, tips not reaching pectoralfin base; bases of barbels arranged in arc along ventral surface of jaw; inner mental barbel about two-thirds outer mental. Posterior process of cleithrum moderately large, almost reaching vertical through base of dorsal-fin spine.
Osteological description. Rostral border of cranium with mesethmoid longer than broad; premaxilla with synchondral articulation; cranial fontanel narrowly elliptical, enclosed by mesethmoid and frontals (Fig. 2). Nasal ossified as short tubular bone situated between mesethmoid cornua and lateral ethmoid, not sutured to mesethmoid. Autopalatine rod-like, oriented almost parallel to longitudinal axis of body; maxilla very small, less than half the size of autopalatine; vomer short, arrow-shaped with lateral processes. Jaws of equal size; premaxilla and dentary slender with three or four rows of robust conical teeth. Anterior nuchal plate absent; middle nuchal plate slightly concave along lateral margins; posterior nuchal plate thin, projected laterally, with prominent tip. Epioccipital process very small.

Hyomandibula broad, projected anteriorly, connected to both quadrate and metapterygoid through cartilage and deeply dentate suture. Metapterygoid as a wide lamina, joined to quadrate via suture (Fig. 3). Quadrate trapezoidal, with broad base, sutured to preopercle, hyomandibula and metapterygoid; long preopercle ventral margins sutured to both quadrate and hyomandibula; suprapreopercle present as short canal bone; opercle laminate, ornamented and broadly subtriangular.

Hyoid arch with parurohyal well developed with a robust ventral process; short dorsal hypohyal associated with comparatively large ventral hypohyal; anterior ceratohyal well developed, posterior ceratohyal smaller than others one; branchiostegal ray articulated to hyoid arch; six branchiostegal rays, four slender rays associated with anterior ceratohyal, two flattened rays with posterior ceratohyal (Fig. 4).

Branchial (gill) arches with urohyal close to basibranchial 2; basibranchial 2 cartilaginous, broadest anteriorly, usually separated by gap from basibranchial 3; basibranchial 3 shorter, forming osseous rod; basibranchial 4 large, flattened and cartilaginous; basibranchial 2 bordered laterally by cartilaginous head of hypobranchial 1; basibranchial 3 between cartilaginous head of hypobranchial 2 and cartilaginous hypobranchial 3; basibranchial 4 bordered laterally by cartilaginous head of ceratobranchial 4 and caudally by cartilaginous head of ceratobranchial 5 . Hypobranchials 1 and 2 subtriangular, mostly osseous, elongate and expanded laterally, with cartilaginous tips; hypobranchial 3 completely cartilaginous, trapezoidal; hypobranchial 4 absent. Five ceratobranchials, mostly ossified, with cartilage on both ends. Ceratobranchials supporting single row of rakers; fifth ceratobranchial expanded postero-medially to support lower pharyngeal toothplate with short conical teeth. Four epibranchials, all largely ossified except for cartilaginous ends, supporting few rakers each, close to articulation with ceratobranchials. Epibranchials 1 and 2 rod-like; epibranchial 3 with posterior uncinate process in articulation to epibranchial 4; epibranchial 4 with laminar extension; reduced accessory cartilage, located on angle between cartilaginous ends of epibranchial 4 and ceratobranchial 4. 
Table 1. Morphometric data for Centromochlus britskii. $\mathrm{SD}=$ Standard deviation; $\mathrm{N}=$ holotype plus 5 specimens.

\begin{tabular}{|c|c|c|c|c|c|}
\hline & Holotype & Range & Mean & $\mathrm{SD}$ & $\mathrm{N}$ \\
\hline Standard length & 39.2 & $33.5-39.2$ & 36.6 & & 6 \\
\hline \multicolumn{6}{|c|}{ Percent of standard length } \\
\hline Body depth & 16.6 & $14.6-17.1$ & 16.2 & 0.85 & 6 \\
\hline Body width & 19.1 & $17.9-19.7$ & 19.1 & 0.67 & 6 \\
\hline Caudal peduncle depth & 9.4 & $9.4-10.9$ & 9.8 & 0.53 & 6 \\
\hline Caudal peduncle length & 22.7 & $20.0-22.7$ & 20.9 & 1.25 & 6 \\
\hline Predorsal length & 32.4 & $31.7-33.4$ & 32.5 & 0.75 & 6 \\
\hline Preanal length (male) & 77.0 & $75.4-77.0$ & 76.2 & 1.17 & 3 \\
\hline Preanal length (female) & & $72.2-72.5$ & 72.3 & 0.17 & 3 \\
\hline Prepelvic length & 57.9 & $56.7-59.6$ & 58.4 & 1.11 & 6 \\
\hline Dorsal origin to pectoral origin & 19.1 & $17.6-20.0$ & 19.0 & 0.81 & 6 \\
\hline Dorsal origin to pelvic origin & 30.6 & $30.6-33.1$ & 32.2 & 0.85 & 6 \\
\hline Pectoral origin to pelvic origin & 35.2 & $35.2-37.2$ & 36.2 & 0.65 & 6 \\
\hline Prepectoral length & 25.0 & $22.5-25.4$ & 24.1 & 1.13 & 6 \\
\hline Dorsal-fin base length & 9.9 & $9.9-12.5$ & 11.0 & 1.03 & 6 \\
\hline Anal-fin base length (male) & 5.4 & $5.4-6.2$ & 5.8 & 0.613 & \\
\hline Anal-fin base length (female) & - & $8.38-10.7$ & 9.7 & 0.983 & \\
\hline Dorsal-fin spine length & 13.3 & $13.3-15.6$ & 14.3 & 0.91 & 6 \\
\hline Pectoral-fin spine length & 22.7 & $20.7-22.7$ & 22.1 & 0.86 & 6 \\
\hline Posterior process of cleithrum length & 16.6 & $15.8-17.1$ & 16.5 & 0.42 & 6 \\
\hline First branched pelvic-fin ray length & 11.7 & $10.9-12.2$ & 11.5 & 0.53 & 6 \\
\hline Longest anal fin ray (male) & 14.5 & $14.5-15.0$ & 14.8 & 0.34 & 3 \\
\hline Longest anal fin ray (female) & - & $30.9-31.6$ & 31.2 & 0.40 & 3 \\
\hline Maxillary barbel length & 32.4 & 24.9-32.4 & 30.3 & 2.74 & 6 \\
\hline Outer mental barbel length & 11.5 & $9.3-11.5$ & 9.8 & 0.84 & 6 \\
\hline Mental barbel length & 7.1 & $6.2-7.8$ & 6.7 & 0.61 & 6 \\
\hline Head length & 23.2 & $22.5-26.6$ & 24.6 & 1.58 & 6 \\
\hline \multicolumn{6}{|c|}{ Percent of head length } \\
\hline Head width & 64.8 & $61.1-65.5$ & 64.0 & 1.68 & 6 \\
\hline Head depth & 52.7 & $46.3-52.7$ & 49.5 & 2.36 & 6 \\
\hline Interorbital distance & 42.9 & $40.0-46.0$ & 42.6 & 2.17 & 6 \\
\hline Left internarial distance & 26.4 & 21.1-26.4 & 25.1 & 2.04 & 6 \\
\hline Anterior internarial distance & 33.0 & $29.2-33.0$ & 31.2 & 1.53 & 6 \\
\hline Posterior internarial distance & 31.9 & $31.5-34.7$ & 33.5 & 1.41 & 6 \\
\hline Snout length & 30.8 & 28.4-31.0 & 29.9 & 0.97 & 6 \\
\hline Orbital diameter & 20.9 & $19.5-23.6$ & 21.8 & 1.51 & 6 \\
\hline Mouth width & 40.7 & $33.7-40.7$ & 38.0 & 2.41 & 6 \\
\hline
\end{tabular}

Pharyngobranchial 1 absent; pharyngobranchial 2 short, cartilaginous, somewhat ellipsoid, placed between anteromedial cartilaginous tips of epibranchials 1 and 2; pharyngobranchial 3 elongate, ossified, with expanded posterior border; pharyngobranchial 4 ossified. Upper pharyngeal tooth plate with conical teeth, supported by pharyngobranchial 3 and 4, and also epibranchials 3 and 4 (Fig. 5).

Infraorbital 1 with ventro-lateral process restricted to anterior border of eye. Infraorbital series completed by four thin and canal-like bones. Lateral line on body straight, inconspicuous, with ossified canal bones only anteriorly, unbranched at caudal fin.
Dorsal fin I,5, dorsal-fin spine with 9 minute serrations becoming progressively smaller towards fin base; spine smooth anteriorly and posteriorly. Pectoral fin I,5, pectoral-fin spine with 16-17 retrorse serrations along entire anterior margin; 13 retrorse serrations along posterior margin; anterior serrations smaller than posterior ones. Pelvic-fin i,5, lateral margin rounded. Adipose fin absent in all specimens. Anal fin iii,7; anal-fin pterygiophores with eight rod-like proximal radials and six cartilaginous distal radials. Caudal fin deeply forked, lobes with rounded tips, $8+9$ principal rays, all branched plus first branched in each lobe; 10-14 upper and 8-13 lower procurrent rays. 
Ribs 9 (one specimen with 10) attached to consecutive vertebrae 6-14, becoming progressively smaller posteriorly. Total vertebrae $32(\mathrm{~N}=2)$ or $33(3)$, observed in cleared and stained (CS) and radiographed specimens (R).

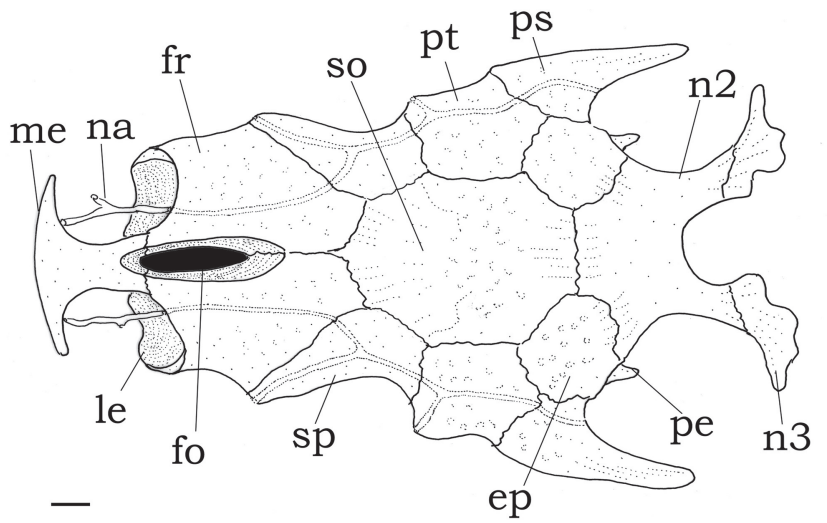

Fig. 2. Neurocranium of Centromochlus britskii, MZUSP 43251, paratype, $35.9 \mathrm{~mm}$ SL. Dorsal view. Abbreviations: ep, epioccipital; fo, cranial fontanel, fr, frontal; le, lateral ethmoid; me, mesethmoid; na, nasal; n2, second nuchal plate; n3, third nuchal plate; pe, posterior epioccipital process; ps, posttemporal-supracleitrum; pt, pterotic; so, supraoccipital; sp, sphenotic. Scale bar $=1 \mathrm{~mm}$.

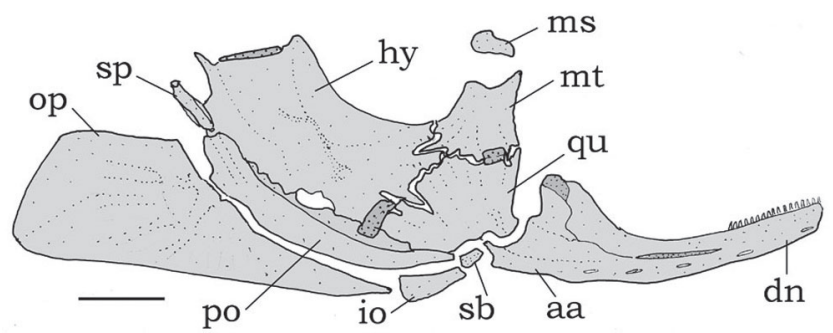

Fig. 3. Right suspensorium of Centromochlus britskii, MZUSP 43251, paratype, $35.9 \mathrm{~mm}$ SL. Lateral view. Abbreviations: aa, angulo-articular; dn, dentary; hy, hyomandibula; io, interopercle; mt, metapterygoid; ms, mesopterygoid; op, opercle; po, preopercle; qu, quadrate; $\mathbf{s b}$, subpreopercle; sp, suprapreopercle. Scale bar $=1 \mathrm{~mm}$.

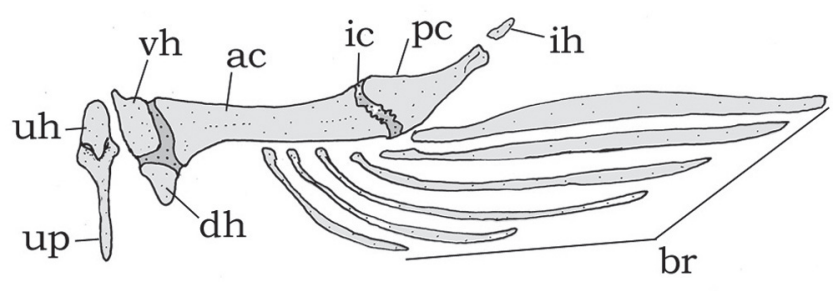

Fig. 4. Right hyoid arch of Centromochlus britskii, MZUSP 43251, paratype, $35.9 \mathrm{~mm}$ SL. Ventral view. Abbreviations: ac, anterior ceratohyal; br, branchiostegal rays; $\mathbf{d h}$, dorsal hypohyal; ic, interceratohyal cartilage; ih, interhyal; pc, posterior ceratohyal; vh, ventral hypohyal; uh, urohyal; up, urohyal ventral process. Scale bar $=1 \mathrm{~mm}$.

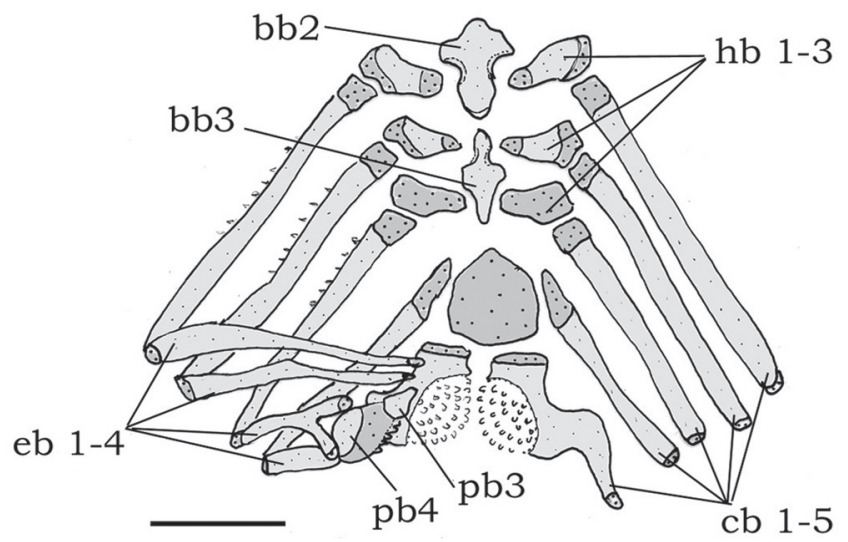

Fig. 5. Pharyngeal arches of Centromochlus britskii, MZUSP 43251, paratype, $35.9 \mathrm{~mm}$ SL. Dorsal view. Abbreviations: bb2, basibranchial 2; bb3, basibranchial 3; bb4, basibranchial 4; cb1-5, ceratobranchials 1 to 5 (anterior to posterior); eb1-4, epibranchials 1 to 4 (anterior to posterior); hb1-3, hypobranchials 1 to 3 ; pb3, pharingobranchial 3; pb4, pharingobranchial 4 . Scale bar $=1 \mathrm{~mm}$.

Color in alcohol. Color dark brown with chromatophores scattered on the head and mid-dorsal portions of body; dorsal surface of head and mid-dorsal line darker, with more concentrated chromatophores. Sides of body with light brown chromatophores, becoming sparse towards belly. Fins almost hyaline; rays mottled with pale brown spots along base. Caudal-fin base with irregular black to brown spots; fin becoming hyaline towards distal margin.

Sexual dimorphism. Based on examination of gonads, Centromochlus britskii attains sexual maturity at about $33.0 \mathrm{~mm}$ SL. Abdominal cavity previously opened in all specimens, revealing most to be adults, the smallest one a maturing female. Genital papilla prominent with a small fleshy tissue around opening in females. The genital papilla of mature males is visible as an emergent deferent duct (Fig. 6, dd). The anal fin of mature males is strongly modified with all proximal radials basally fused to each other, forming a singular structure. Third unbranched ray elongated and thickened, ending in a rounded tip, together with the slim first branched ray (Fig. 6, uiii, b1). First unbranched anal-fin ray thickened and short. Second unbranched ray elongated, with an intermediate size between the neighboring first and third rays. Third unbranched ray longest, twice the width of first branched ray, bearing 13-15 segments (Fig. 6, uiii, b1). Posterior branched rays progressively shorter; last ray the smallest one (Fig. 6, b7). No tegumentary keel preceding the first unbranched anal-fin ray; denticulations absent from anterior rays. No modifications observed in the maxillary barbel and in the dorsal-fin spine of males, unlike some species of Auchenipteridae (e.g., Auchenipterus), wherein modified males have stiff and/or spiny ossified maxillary barbels, and an elongated dorsal-fin spine (Ferraris \& Vari, 1999; Reis \& Borges, 2006; Ribeiro \& Rapp Py-Daniel, 2010). 


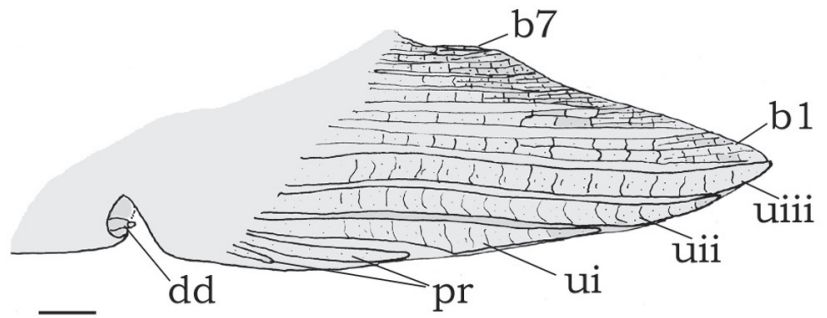

Fig. 6. Male modified anal fin of Centromochlus britskii, MZUSP 43251, paratype, $38.6 \mathrm{~mm}$ SL. Left side in lateral view. Abbreviations: b1, first branched ray; b7, seventh branched ray; dd, deferent duct; pr, unsegmented procurrent anal fin rays (not counted); ui, unbranched first ray; uii, second unbranched ray; uiii, third unbranched ray. Scale bar $=1 \mathrm{~mm}$.

Distribution. Centromochlus britskii is known from its type locality in the rio Paraná basin near Ilha Solteira, where now is the reservoir of the UHE Ilha Solteira (Fig. 7), in the upper rio Paraná basin, São Paulo, Brazil.

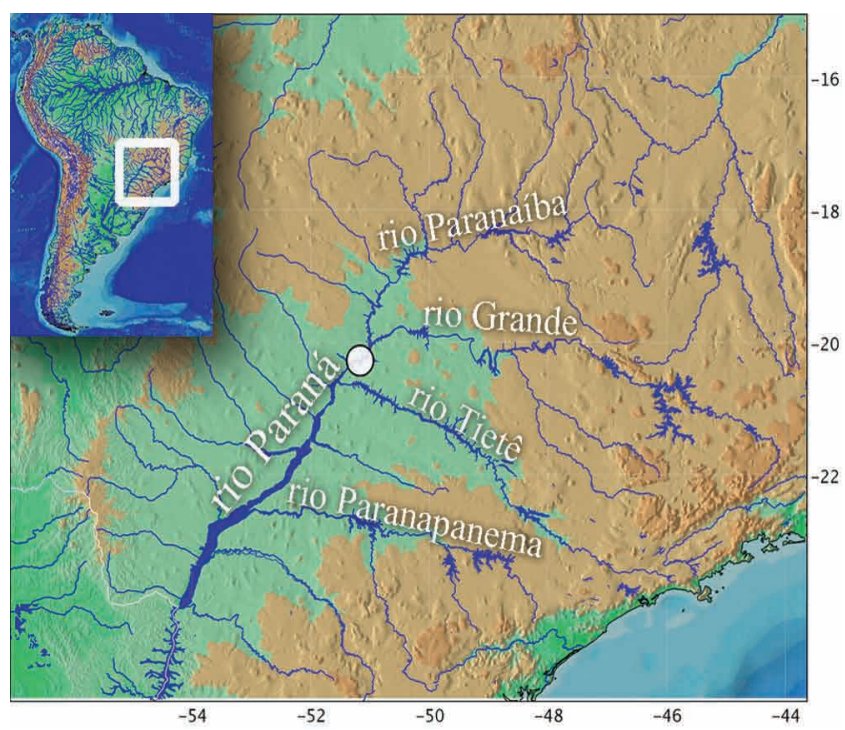

Fig. 7. Map of southeast South America indicating the rio Paraná in UHE Ilha Solteira, type-locality of Centromochlus britskii.

Ecological notes. The species is known only from a single sample in 1965, prior to the completion of UHE Ilha Solteira; specimens were collected in places with rocks and rapids near cofferdams in the main channel of the upper rio Paraná. The rio Paraná in that area is now modified as a large reservoir. Analysis of the stomach contents revealed the presence of insect larvae, including Chironomidae, and other invertebrate fragments.

Etymology. The specific name honors Dr. Heraldo Antonio Britski, who collected the type material, for his significant contributions and pioneer studies on the systematics of the catfish family Auchenipteridae (i.e, Britski, 1972).

\section{Discussion}

Three species of Centromochlinae occur in the upper rio Paraná basin: Tatia neivai (Ihering, 1930), Glanidium cesarpintoi, and Centromochlus britskii, described herein. Tatia neivai was described based on the unique holotype that is currently lost (Britski, 1969), and recently redescribed (Sarmento-Soares \& Martins-Pinheiro, 2008). Specimens of Centromochlus britskii were previously misidentified as Glanidium cesarpintoi (Sarmento-Soares \& Buckup, 2005). Specimens recently collected confirm the distinctiveness of G. cesarpintoi and C. britskii. Glanidium cesarpintoi differs by having an adipose fin (vs. absent in C. britskii), anterior nuchal plate present ( $v s$. absent), anal-fin radials of mature males only partially fused (vs. completely fused), anal fin with 8 branched rays (vs. 7) and bearing 21-23 segments in mature males (vs. 13-15). Glanidium cesarpintoi is currently known from specimens collected from its type locality, rio Mogi Guaçu, a tributary of rio Grande, rio Tibagi, a tributary of rio Paranapanema, and rio Corumbá, a tributary of rio Paranaíba (see Material Examined).

The new species occurred in sympatry with Tatia neivai, in the rio Paraná prior to the Ilha Solteira reservoir. Tatia neivai has the diagnostic features of Tatia, such as the suspensorium with metapterygoid bone united to the quadrate only ( $v s$. joined to both quadrate and hyomandibula in C. britskii; see fig. 2 in Sarmento-Soares \& Martins-Pinheiro, 2008 and Fig. 3 in present paper); caudal peduncle with a middorsal keel posterior to adipose fin (vs. caudal peduncle rounded dorsally, lacking keel in C. britskii). Tatia neivai also has an anterior nuchal plate (vs. absent in C. britskii); penultimate centrum without ribs (vs. pleural ribs attached to consecutive vertebra in C. britskii); and head, body and fins dark with small pale blotches (vs. head, body and fins light brown with scattered dark chromatophores).

The new species is particularly similar to Centromochlus simplex (see below for comments on the latter), which has a diminutive adipose fin, 6-7 branched anal-fin rays and retrorse serrations along both margins of pectoral-fin spine. The new species is distinguished from $C$. simplex by having an adipose fin (vs. adipose fin absent in C. britskii); 17 upper plus 15 lower caudal fin procurrent rays ( $v s .9$ upper plus 8 lower) and longer posterior cleithral process, $20 \%$ of SL (vs. $16 \%$ of SL). The new species is also very similar to Centromochlus bockmanni, a species apparently endemic to the rio São Francisco basin. Centromochlus bockmanni is distinguished by having adipose fin ( $v s$. absent in $C$. britskii), caudal fin procurrent rays 14 upper plus 13 lower (vs. 9 upper plus 8 lower); pectoral-fin spine with antrorse serrations along anterior margin and retrorse serrations along posterior margin ( $v s$. retrorse serrations along both anterior and posterior margins).

The new species is herein described in the genus Centromochlus by possessing an elongated maxilla that extends into the maxillary barbel; infraorbital 1 with an 
elongate ventrolateral process, forming anterior border of orbit; and a longitudinal crest on the parasphenoid and orbitosphenoid for attachment of the adductor arcus palatini (Soares-Porto, 1998; Sarmento-Soares \& Porto, 2006). In addition, Centromochlus britskii lacks the features used to diagnose the other genera of Centromochlinae, namely Tatia, Glanidium and Gelanoglanis. Tatia was defined by Sarmento-Soares \& Martins-Pinheiro (2008) as having hyomandibula elongated anterodorsally, not contacting the narrow metapterygoid, anal-fin base of adult males reduced and caudal peduncle compressed and deep, somewhat keeled posterior to adipose fin. Glanidium is diagnosed by having sphenotic and pterotic excavated, resulting in strongly concave lateral margin of neurocranium (Ferraris, 1988; Soares-Porto, 1998); presence of anterior nuchal plate, and anal-fin radials not completely fused in mature males. Gelanoglanis is a miniature and derived taxon of Centromochlinae with several autapomorphies (see Introduction). Although the new species is demonstrably valid, problems persist concerning the taxonomy of some species of Centromochlus.

Comments on Centromochlus simplex. Until recently, Tatia simplex Mees, 1974 was only known from the holotype collected in the rio das Mortes, rio Araguaia basin. Tatia simplex is a valid taxon within the centromochlin subfamily, a clade characterized by the following three synapomorphies, exclusive to adult males: modified anal-fin rays and proximal radials with a posterior orientation; urogenital papillae emerging from a skin flap at anal-fin origin; and proximal radials basally fused to each other, forming a single ossification (Soares-Porto, 1998). Sarmento-Soares \& Martins-Pinheiro (2008) recently revised Tatia, diagnosing it based on the following exclusive characteristics: suspensorium with metapterygoid united to quadrate but not to hyomandibula and caudal peduncle with a middorsal keel posterior to adipose fin. Based on examinations of the holotype and additional specimens from the Tocantins and Xingu river basins, Sarmento-Soares \& Martins-Pinheiro (2008) treated T. simplex as "Centromochlus" simplex incertae sedis in Centromochlinae because it lacks all characteristics diagnostic of Tatia (e.g., suspensorium is joined to both quadrate and hyomandibula in $C$. simplex). Centromochlus simplex also lacks the features used to diagnose Glanidium (Soares-Porto, 1998; Sarmento-Soares $\&$ Martins-Pinheiro, 2013), such as voluminous section A2 of the adductor mandibulae muscle associated with a deep concavity between sphenotic and pterotic, and anterior nuchal plate present. Centromochlus simplex does not share the unique features present in Gelanoglanis described in Soares-Porto et al. (1999) and Rengifo et al. (2008), already mentioned in the introduction.

At present, Centromochlus is a morphologically heterogeneous assemblage of species supported by the following synapomorphies: presence of an elongate maxilla that extends into the maxillary barbel; an elongate ventrolateral process of infraorbital 1, forming anterior border of orbit; and a longitudinal crest on the parasphenoid and orbitosphenoid for attachment of the muscle adductor arcus palatini (Soares-Porto, 1998; Sarmento-Soares \& Porto, 2006). Although some variation occurs within Centromochlus and further investigation of its monophyly are necessary, $C$. simplex shares all those features hypothesized for Centromochlus as synapomorphies. In addition, the lack of anterior nuchal plate is a feature common to some species of Centromochlus and Gelanoglanis. Based on our observations, Tatia simplex is herein considered as a member of genus Centromochlus.

Material examined. Centromochlus altae. Colombia. USNM 121965, 1, $35.5 \mathrm{~mm} \mathrm{SL}$, río Dedo, tributary of río Orteguazo. Centromochlus concolor. Brazil. Pará State. MZUSP 31878, 1, 48.7 mm, rio Tapajós, Alter do Chão. MZUSP 8535, 6, 1 CS, 46.5$76.5 \mathrm{~mm}$ SL, rio Tapajós, Santarém. Centromochlus existimatus. Brazil. Acre State. MZUSP 48880, 1, 90.2 mm SL, Porto de rio Branco, rio Branco. Centromochlus heckelii. Brazil. Acre State. MZUSP 48910, 2, 80.0-83.2 mm SL, rio Acre between seringal Paraíso and lagoa Amapá. Pará State. MZUSP 8336, 2 CS, 53.4$62.0 \mathrm{~mm}$ SL, rio Tapajós, Santarém. Amazonas State. INPA 8203, 2, 73.3-81.8 mm SL, Manacapuru. INPA 10967, 2, 106.2-108.7 mm SL, rio Jamari. Centromochlus macracanthus. Brazil. Amazonas State. INPA 6565, 1, 129.7 mm SL, rio Negro. MZUSP 30605, 2, 65.7-71.8 mm SL, paratypes, rio Negro, Cachoeira de São Gabriel. Centromochlus meridionalis. Brazil. Mato Grosso State. MBML 5616, 1 CS, $39.1 \mathrm{~mm}$ SL, MBML 5617, 3, 32.2-46.2 mm SL, MNRJ 40702, 3, 32.6-38.3 mm SL, Córrego Loanda, a small tributary of rio Roquete, Cláudia. Centromochlus perugiae. Brazil. Acre State. MZUSP 31880, 1, 28.2 mm SL, rio Tarauacá, Tarauacá. Ecuador. MNRJ 30489, 1, 38.5 mm SL, rio Aguari, Napo. Peru. MNRJ 30490, 1, 38.4 mm SL, Huanuco, Amazonas. MZUSP 26029, 2, 22.3-29.8 mm SL, rio Chiriaco, provincia Bagua. MZUSP 26684, 4, 26.2-35.9 mm SL, arroyo de Ivita-Pucallpa, Caserio Neshuya, Provincia Coronel Portillo, Ucayali. Centromochlus punctatus. Brazil. Pará State. INPA 18480, 2, 35.8-37.0 mm SL, rio Tocantins, Tucurui, Igarapé Tucuruizinho. MZUSP 31877, 1, 29.7 mm, rio Itacaiunas, Caldeirão, Cachoeira Carreira Comprida, Serra dos Carajás. Centromochlus reticulatus. Guyana. RMNH. PISC 26744, 2 R, 18.3-39.8 mm SL, paratypes, Karanambo, Rupununi. Centromochlus romani. Venezuela. AMNH 91382, 2, 32.5-32.7 mm SL, rio Siapa, Amazonas. Centromochlus schultzi. Brazil. Goiás State. MNRJ 12139, 10 of 38, 1 CS, 85.0-108.9 mm SL, Serra da Mesa dam, upper rio Tocantins. Mato Grosso State. MNRJ 9417, 2, 32.7-60.8 mm SL, upper rio Xingu. Centromochlus simplex. Brazil. Mato Grosso: BMNH 1971.7.29: 5, 1, $28.2 \mathrm{~mm}$ SL, holotype of Tatia simplex: Xaventina, rio das Mortes; MZUSP 47506, 1 CS, Igarapé do Aeroporto, Humboldt, Aripuanã. MZUSP 36862, 2, 28.4- 29.6 mm SL, rio Xingu. MZUSP 82350, 3, 26.2$27.1 \mathrm{~mm}$ SL, rio Tocantins. Pará: MZUSP 36862, 3, 28.1-29.3 mm SL, rio Xingu. MZUSP 44071, 2, 45.0-47.7 mm SL, lake in front of Jatobal, rio Tocantins; MZUSP 44074, 1, 27.9 mm SL, lake near Capitariquara channel, near Jatobal, rio Tocantins. INPA 18475, 1, $19.9 \mathrm{~mm}$ SL, rio Tocantins, Jatobal rapids. 
Glanidium cesarpintoi. Brazil. Goiás: MNRJ 41724, 3, 1 CS, 65.2-83.2 mm SL, NUP 5699, 7, 77.7-87.9 mm SL, rio Corumbá (Areia), tributary of rio Paranaíba, Pires do Rio near boundary with Ipameri. São Paulo: DZSJRP 4570, 1 R, 89.7 mm SL, Salto Grande Reservoir, downstream. DZSJRP 6343, 1, $13.6 \mathrm{~mm}$ SL, rio Borá, between Nova Aliança and Potirendaba. Paraná: MZUEL 108, 1, $85.5 \mathrm{~mm}$ SL, $1 \mathrm{CS}, 95.7 \mathrm{~mm}$ SL, rio Tibagi, 2321'9"S 5100'52"W; MZUEL 5392, 1, 94.3 mm SL, rio Tibagi at Limoeiro, $23^{\circ} 21^{\prime} 9$ 'S $51^{\circ} 00^{\prime} 52^{\prime \prime} \mathrm{W}$.

Tatia neivai. Brazil. São Paulo: MZUSP 42570, 1 CS, 60.5 $\mathrm{mm}$ SL, lake on rio Atibaia, near Jaguariuna; MZUSP 47505, 7, 53.1-62.1 mm SL, Ilha Solteira, rio Paraná, Ilha Solteira dam.

\section{Acknowledgments}

We herein express our deepest gratitude to Heraldo A. Britski for advising our PhD dissertations on auchenipterid catfishes. We wish to thank our colleagues at the MBML and MZUEL for their assistance. We acknowledge Ronaldo F. Martins-Pinheiro for collaboration with geo-referenced base maps, and Alberto Akama, Mark H. Sabaj-Pérez and anonymous reviewers for revisions to a previous version of manuscript. For loans, exchange of specimens and/or courtesies extended during visits to their institutions we thank Scott A. Schaefer (AMNH), Francisco Langeani (DZSJRP), Lucia Rapp Py-Daniel (INPA), Paulo A. Buckup, Marcelo R. Britto (MNRJ), Heraldo A. Britski, Osvaldo T. Oyakawa (MZUSP), Ronald de Ruiter (RMNH. PISC), Sandra Raredon and Richard P. Vari (USNM). To the Conselho Nacional de Desenvolvimento Científico e Tecnológico $(\mathrm{CNPq})$ for funding resources through Universal Project process 471963/2013-5 and PCI- E1 grant, process 465023/2014-2 (to LMSS).

\section{References}

Akama, A. \& L. M. Sarmento-Soares. 2007. Família Auchenipteridae. Pp. 116-120. In: Buckup, P. A., N. A. Menezes \& M. S. Ghazzi (Eds.). Catálogo das espécies de peixes de água doce do Brasil. Rio de Janeiro, Museu Nacional, Universidade Federal do Rio de Janeiro. Série Livros, 23.

Arratia, G. 2003. Catfish head skeleton - an overview. Pp. 20-46. In: Arratia, G., B. G. Kapoor, M. Chardon \& R. Diogo (Eds.). Catfishes. Enfield, New Hamphire, Science Publishers. v. 1.

Birindelli, J. L. O. 2014. Phylogenetic relationships of the South American Doradoidea (Ostariophysi: Siluriformes). Neotropical Ichthyology, 12: 451-564.

Bleeker, P. P. 1862. Atlas Ichthyologique des Indes Orientales Néêrlandais. 2. Siluroides, Chacoides et Hétérobranchoides. Publié sous les Auspices du Gouvenement Colonial Néêrlandais. J. Smith and Gide, Amsterdam.

Böhlke, J. 1980. Gelanoglanis stroudi: A new catfish from the Rio Meta system in Colombia (Siluriformes, Doradidae, Auchenipterinae). Proceedings of the Academy of Natural Sciences of Philadelphia, 132: 150-155.

Brasil. MMA- Ministério do Meio Ambiente. 2014. Portaria $\mathrm{N}^{\circ}$ 445, de 17 de Dezembro de 2014. Lista Nacional Oficial de Espécies da Fauna Ameaçadas de Extinção Peixes e Invertebrados Aquáticos. Anexo I, Anexo II. Available from: http://www.lex.com.br/legis_26308276_PORTARIA_N_445 DE_17_DE_DEZEMBRO_DE_2014.aspx (06 Mar 2015).

Britski, H. A. 1969. Lista dos tipos de peixes das coleções do Departamento de Zoologia da Secretaria de Agricultura de São Paulo. Papeis Avulsos de Zoologia, 22: 197-215.

Britski, H. A. 1972. Sistemática e evolução dos Auchenipteridae e Ageneiosidae (Teleostei, Siluriformes). Unpublished Ph. D. Dissertation, Universidade de São Paulo, São Paulo, 141p.

Britto, M. R. 2002. Análise filogenética da ordem Siluriformes com ênfase nas relações da superfamília Loricarioidea (Teleostei: Ostariophysi). Unpublished Ph. D. Dissertation, Universidade de São Paulo, São Paulo, 512p.

Campos-da-Paz, R. 2000. On Sternarchorhynchus Castelnau: A South American Electric Knifefish, with Descriptions of Two New Species (Ostariophysi: Gymnotiformes: Apteronotidae). Copeia, 2000: 521-535.

De Filippi, P. 1853. Nouvelles espèces de poissons. Revue et Magasin de Zoologie Pure et Appliquée, 5: 164-171.

Ferraris, C. J., Jr. 1988. The Auchenipteridae: putative monophyly and systematics, with a classification of the neotropical doradoid catfishes (Ostariophysi: Siluriformes). Unpublished $\mathrm{Ph}$. Dissertation, City University of New York, 229p.

Ferraris, C. J., Jr. 2003. Family Auchenipteridae (Driftwood catfishes). Pp. 470- 482. In: Reis, R. E., S. O. Kullander \& C. J. Ferraris, Jr. (Eds.). Checklist of the freshwater fishes of South and Central America. Porto Alegre, Edipucrs.

Ferraris, C. J., Jr. 2007. Checklist of catfishes, recent and fossil (Osteichthyes: Siluriformes), and catalogue of siluriform primary types. Zootaxa, 1418: 1-628.

Ferraris, C. J., Jr. \& R. P. Vari. 1999. The South American catfish genus Auchenipterus Valenciennes, 1840 (Ostariophysi: Siluriformes: Auchenipteridae): monophyly and relationships, with a revisionary study. Zoological Journal of the Linnean Society, 126: 387-450.

Fink, S. V. \& W. L. Fink. 1981. Interrelationships of the ostariophysan fishes (Teleostei). Zoological Journal of the Linnean Society, 72: 297- 353.

Fowler, H. W. 1945. Colombian zoological survey. Part I.B. The freshwater fishes obtained in 1945. Proceedings of the Academy of Natural Sciences of Philadelphia, 97: 93-135.

Gill, T. H. 1870. On some new species of fishes obtained by Prof. Orton from the Maranon, or Upper Amazon, and Napo Rivers. Proceedings of the Academy of Natural Sciences of Philadelphia, 22: 92-96.

Hoedeman, J. J. 1961. Notes on the ichthyology of Surinam and other Guianas. Bulletin Aquatic Biology, 2: 129-139.

Ihering, R. von. 1928. Glanidium cesarpintoi $\mathrm{n}$. sp. de peixe de couro (fam. Siluridae sub-fam. Auchenipterinae). Boletim Biologico, Laboratorio de Parasitologia, Faculdade de Medicina de São Paulo, 12: 46-49.

Ihering, R. von. 1930. Notas ecológicas referentes a peixes d'água doce do Estado de S. Paulo e descripção de quatro espécies novas. Archivos do Instituto Biológico, São Paulo, 3: 93-103.

Kner, R. 1858. Ichthyologische beiträge. II. Abtheilung Sitzungsberichte der Akademie der Wissenschaften in Wien, Mathematisch-Naturwissenschaftlich. Klasse 26: 373- 448.

Lütken, C. F. 1875. Velhas-Flodens Fiske. Et Bigrag til Brasiliens Ichthyologi. Elfter Professor J. Reinhardt Indsamlinger og Optegnelser. Kongelige Danske Videnskabernes Selskab Kiøbenhavske, 12: 121-253. 
Mees, G. F. 1974. The Auchenipteridae and Pimelodidae of Suriname (Pisces, Nematognathi). Zoologische Verhandelingen, 132: 1-256.

Miranda Ribeiro, A. 1911. Fauna brasiliense. Peixes. Tomo IV (A) [Eleutherobranchios Aspirophoros]. Arquivos do Museu Nacional do Rio de Janeiro, 16: 1-504.

Pavanelli, C. S. \& A. G. Bifi. 2009. A new Tatia (Ostariophysi: Siluriformes: Auchenipteridae) from the rio Iguaçu basin, Paraná State, Brazil. Neotropical Ichthyology, 7: 199-204.

Reis, R. E. \& T. A. K. Borges. 2006. The South American Catfish Genus Entomocorus (Ostariophysi: Siluriformes: Auchenipteridae), with the Description of a New Species from the Paraguay River Basin. Copeia, 2006: 412-422.

Rengifo, B., N. K. Lujan, D. Taphorn \& P. Petry. 2008. A new species of Gelanoglanis (Siluriformes: Auchenipteridae) from the Marañon River (Amazon Basin), northeastern Perú. Proceedings of the Academy of Natural Sciences of Philadelphia, 157: 181-188.

Ribeiro, F. R. V. \& L. H. Rapp Py-Daniel. 2010. Ageneiosus uranophthalmus, a new species of auchenipterid catfish (Osteichthyes: Siluriformes) from river channels of the central Amazon basin, Brazil. Neotropical Ichthyology, 8: 97-104.

Rössel, F. 1962. Centromochlus schultzi, ein neues wels aus Brasilien (Pisces, Teleostei, Auchenipteridae). Senckenbergiana Biologica, 43: 27-30.

Royero, R. 1992. Tatia musaica, una nueva especie de bagre auquenipterido (Siluriformes-Auchenipteridae) de la cuenca del Rio Orinoco, Territorio Federal Amazonas, Venezuela. Acta Científica Venezuelica, 43: 300-306.

Sarmento-Soares, L. M., F. G. Cabeceira, L. N. Carvalho, J. Zuanon \& A. Akama, 2013. Centromochlus meridionalis, a new catfish species from the southern Amazonian limits, Mato Grosso State, Brazil (Siluriformes: Auchenipteridae). Neotropical Ichthyology, 11: 797- 808.

Sarmento-Soares, L. M. \& P. A. Buckup. 2005. A new Glanidium from the rio São Francisco basin, Brazil (Siluriformes: Auchenipteridae: Centromochlinae). Copeia, 2005: 846853.

Sarmento-Soares, L. M. \& R. F. Martins-Pinheiro. 2008. A systematic revision of Tatia (Siluriformes: Auchenipteridae: Centromochlinae). Neotropical Ichthyology, 6: 495-542.

Sarmento-Soares, L. M. \& R. F. Martins-Pinheiro. 2013. Glanidium botocudo, a new species from the rio Doce and rio Mucuri, Minas Gerais, Brazil (Siluriformes: Auchenipteridae) with comments on taxonomic position of Glanidium bockmanni Sarmento-Soares \& Buckup. Neotropical Ichthyology, 11: 265-274.

Sarmento-Soares, L. M. \& M. Porto. 2006. Comparative anatomy of the cheek muscles within the Centromochlinae subfamily (Ostariophysi, Siluriformes, Auchenipteridae). Journal of Morphology, 267: 187-197.
Shibatta, O. A. \& J. H. P. Dias. 2006. 40 peixes do Brasil: CESP 40 anos. Rio de Janeiro, Doiis. 207p.

Soares-Porto, L. M. 1998. Monophyly and interrelationships of the Centromochlinae (Siluriformes, Auchenipteridae). Pp. 331-350. In: Malabarba, L. R., R. E. Reis, R. P. Vari, Z. M. S. Lucena \& C. A. S. Lucena (Eds.). Phylogeny and Classification of Neotropical fishes. Porto Alegre, Edipucrs.

Soares-Porto, L. M. 2000. A new species of Centromochlus (Siluriformes: Auchenipteridae) from the rio Negro drainage, Amazon basin, Brazil, with comments on its relationships. Ichthyological Explorations of Freshwaters, 11: 279-287.

Soares-Porto, L. M., S. J. Walsh, L. G. Nico \& J. M. Netto. 1999. A new species of Gelanoglanis from the Orinoco and Amazon River basins, with comments on miniaturization within the genus (Siluriformes: Auchenipteridae: Centromochlinae). Icthyological Exploration of Freshwaters, 10: 63-72.

Steindachner, F. 1883. Beiträge zur Kenntnis der Flussfische Südamerika's, IV. Denkschriften der Akademie der Wissenschaften in Wien, MathematischNaturwissenschaftlichen, 46: 1-44.

Taylor, W. R. \& G. Van Dyke, 1985. Revised procedures for staining and clearing small fishes and other vertebrates for bone and cartilage study. Cybium, 9: 107-119.

Triques, M.L. 1998. Tembeassumarauna, new genus and species of electrogenic neotropical fish (Ostariophysy: Gymnotiformes: Apteronotidae). Revue Francese de Aquariologie, 25: 5-10.

Triques, M. L. 2011. Apteronotus acidops, new species of long snouted electric fish (Teleostei: Gymnotiformes: Apteronotidae) from the upper rio Paraná basin in Brazil, with a key to the apteronotid species from the area. Vertebrate Zoology, 61: 299- 306.

Vari, R. P. \& B. B. Calegari. 2014. New species of the catfish genus Tatia (Siluriformes:Auchenipteridae) from the rio Teles Pires, upper rio Tapajós basin, Brazil. Neotropical Ichthyology, 12: 667-674.

Vari, R. P. \& C. J. Ferraris, Jr. 2013. Two new species of the catfish genus Tatia (Siluriformes: Auchenipteridae) from the Guiana Shield and a reevaluation of the limits of the genus. Copeia, 2013: 396-402.

Weitzman, S. H. 1962. The osteology of Brycon meeki, a generalized characid fish, with an osteological definition of the family. Stanford Ichthyological Bulletin, 8: 1- 77.

ZFIN Project - Zebrafish Model Organism Database (ZFIN), Zebrafish Anatomical Ontology, University of Oregon, Eugene, OR 97403-5274. Available from: http://zfin.org/ action/anatomy/anatomy-search. (25 Aug 2012).

Submitted March 24, 2014

Accepted October 23, 2014 by Francisco Langeani

Published March 31, 2015 